\section{Ukrainian Journal \\ of Educational Studies and Information Technology}

ISSN: 2521-1234 online

Ukr. J. of Educ. Stud. and Inf. Technol., 7(4), 31-36

doi: 10.32919/uesit.2019.04.04

Vol. 7, Issue 4, 2019

UDC [004.38:378.147]=111

\title{
Peculiarities of tablet PC application for ESP learning at agrarian and technical universities
}

\author{
Svitlana Symonenko, Viktoriia Lemeshchenko-Lagoda, Oleksandr Kurashkin \\ Dmytro Motornyi Tavria State Agrotechnological University, \\ Melitopol, Ukraine
}

\begin{tabular}{|c|c|}
\hline ARTICLE INFO & ABSTRACT \\
\hline History: & \multirow{11}{*}{$\begin{array}{l}\text { The article presents the analysis of the use of tablet computers for } \\
\text { training students of agricultural and technical universities. The } \\
\text { statistics confirms the increasing use of computers of this type for } \\
\text { studying different disciplines. It is emphasized that the introduction } \\
\text { of using tablet computers as an effective tool for learning foreign } \\
\text { languages is a crucial problem, despite many positive features. The } \\
\text { main advantages and disadvantages of introduction of tablet } \\
\text { computers into the educational process are outlined. The advantages } \\
\text { of tablet PC application are: easy access to information, use of } \\
\text { multimedia and interactivity, better interaction between students } \\
\text { and teachers, new ways of document and image processing, } \\
\text { possibilities of distant education, reasonable cost. The main } \\
\text { disadvantages are vision problems. It is noted that the process of } \\
\text { learning a foreign language for special purposes requires the } \\
\text { creation of a mixed learning environment, in which a new type of } \\
\text { cooperation between teachers and students emerges, and the main } \\
\text { purpose of the classes is to solve problems related to the future } \\
\text { professional activity in the friendly environment. Certain examples } \\
\text { of tablet computer application for learning English for special } \\
\text { purposes for students of agricultural and technical specialities are } \\
\text { given. }\end{array}$} \\
\hline Received: 30.11.2019 & \\
\hline Accepted: 20.12.2019 & \\
\hline Published online: 30.12 .2019 & \\
\hline & \\
\hline tablet PC & \\
\hline $\begin{array}{l}\text { English for specific purposes (ESP) } \\
\text { language competence } \\
\text { interaction skills } \\
\text { foreign language proficiency }\end{array}$ & \\
\hline (C) S. Symonenko & \\
\hline (c) Viktoriia Lemeshchenko-Lagoda & \\
\hline (c) Oleksandr Kurashkin & \\
\hline $\begin{array}{l}\text { This work is licensed under a "CC BY } \\
\text { 4.0" license. }\end{array}$ & \\
\hline
\end{tabular}

\section{INTRODUCTION}

One of the priority directions in the modern society development is the informatization of education - providing the methodology and practice of using modern or new information and communication technologies, oriented on realization of psychological and pedagogical goals of education on all its levels.
The purpose of the modern education system is not to overload the student with basic knowledge, most of which will never be required, but to form the skills of successful social adaptation, cooperation and ability to educate oneself.

A staff member of the Institute of Innovative Technologies and Content of Education N. Guschina declared: "Education must prepare 
people to be successful in the 21 st century. If we look at our old programs, standards, forms and teaching methods, we will find that all these do not correspond to the basic competencies needed today" (Yuzych, \& Shchedrov, 2013).

Therefore over the past few years, a number of documents that outline new trends and directions of the education system have been adopted. One of them is the Presidential Decree on the National Strategy for the Development of Education in Ukraine until 2021. The main purpose of the decree is "to increase the availability of quality, competitive education in accordance with the requirements of innovative sustainable development of society, economy" and "to ensure the personal development of a person according to his individual abilities, needs based on lifelong learning." It is expected that the implementation of the strategy will improve the quality of national education and its innovative development in accordance with world standards. And it also will contribute to "a significant increase in the intellectual, cultural, spiritual and moral potential of society and the individual," as it was noted (Yuzych, \& Shchedrov, 2013).

These changes set new tasks in preparing future specialists in different fields at higher education institutions. In other words the educational environment for the future specialists preparation should be formed primarily as an information one, which uses new information technologies and modern technical means of teaching. The components of such an information environment include tools for organizing the process of effective learning through the use of digital educational resources. Such technical means firstly include devices for the visual presentation of educational messages to students. The introduction of such devices in the educational process allows to intensify the educational process, to create problematic situations in the learning process, to activate the cognitive activity of students, to increase the interest of students in the subject, to provide better presentation of material and enables the solving of cross-curricular tasks. At the same time, it is necessary to understand that the presence of the most advanced information technologies cannot solve all the tasks of the educational process.
The analysis of the pedagogical literature shows that the problem of informational training of the future specialists in higher educational institutions has been the subject of research of many scientists, such as V. Yu. Bykov, V. I. Grishin, M. I. Zhaldak, E. I. Mashbits, M. I. Shkil , S. M. Yashanov, and others (Bovtruk, 2014). But it is obvious that use of such devices as tablet PCs, despite of their popularity, is underestimated.

The objective of this article is to analyse how tablets PCs can change the educational process, especially while teaching the "English for specific purposes" course at the agrarian and technical universities.

\section{RESEARCH RESULTS}

The Tablet PC is the next-generation mobile PC, power, versatility, and portability of which make it the ideal solution for students. Some scholars define tablet PCs as full-size IBM PCcompatible laptops equipped with a touch screen that allows users to work with the stylus or fingers, both using and without using the keyboard and mouse (Bovtruk, 2014).

Today tablets are increasingly being used in the educational process around the world. According to the recent researches the vast majority of modern students believe that tablets will change the learning process in the future (81\%) and therefore students will buy digital textbooks instead of printed ones (82\%). This was the result of Harris Poll's 2014 Student Mobile Device Survey commissioned by Pearson. The vast majority of respondents (74\%) said that tablets make the learning process more enjoyable. The survey was conducted on the Harris Poll website between February 13 and March 12, 2014. Respondents were 1,228 US students aged 18 to 30 who had attended college, university or postgraduate programs (Tablets will change higher education, 2014).

Although tablets are very popular among students, only less than half of students regularly use tablets (45\%) for training, and only 1 in 10 students (11\%) regularly use hybrid models with keyboards (Tablets will change higher education, 2014). 
Therefore, we can emphasize that implementation of tablet PC technology as an effective tool in teaching different subjects faces different challenges. Moreover, tablet PCs are widely used only for teaching such subjects as Engineering, Architecture, Arts and Design etc., while in the sphere of foreign languages, especially teaching English for specific purposes (ESP) we can observe the lack of this technology implementation despite of all its benefits for students and teachers.

Firstly, tablet PCs provide an easy access to information. Students can easily use any Internet resources as well as electronic copies of all required textbooks which can be downloaded or read online. It enables focusing on all required data without attending libraries in order to find and work out different analyses and reports.

Secondly, tablet PC technology enables to use multimedia and interactive content. The possibilities of paper textbooks are limited by the provision of textual and graphic information. Using electronic sources it is possible to watch and listen to audio and video content. By using video materials, you can significantly increase the visibility and interest of students. In addition, it is possible to use different interactive elements like virtual models of different equipment etc (Sandakov, 2013).

Thirdly, tablet PCs provide better interaction between students and teachers. Thus teachers can send the students either assignments or learning materials via LAN or Wi-Fi and by the end of the lesson students can accumulate all files with completed tasks and materials they will need to study and review. This way this device allows students to add new data, images etc, giving teachers the opportunity to work side by side with their students.

Fourthly, tablet PCs allow users to "mark up" the documents, annotate on images and highlight the most important parts and passages attracting students' attention to the highly complicated concepts and cases (Carrillo, Cejudo, Domínguez, \& Rodríguez, 2013).

Fifthly, tablet PCs have a great potential for use as distant education tools, sending all the materials like audio lectures, handwritten materials, electronic slides for those students who cannot attend classes due to different health problems etc.

Finally, they have democratic cost. The price of a budget tablet is more or less comparable to the cost of a set of study aids for 2-3 years of study. (Semerci, 2018)

Speaking about incontestable benefits of tablet PCs it is necessary to focus on some of their disadvantages. One of the most important of them is eye concentration. Any monitor puts extra strain on the vision organs. According to professional developer opinions, a comfortable screen size of at least 15 inches is required; 13 inches is a trade-off between convenience and mobility; a screen size of 11 inches or less is suitable for communication and entertainment, but not for serious work. The small screen size is extremely inconvenient for working with text and may have negative effects on eyesight (Sandakov, 2013).

Summing up all advantages and disadvantages it should be emphasized that tablet PCs are definitely worth using in the educational process.

As Dr. R. Sivakumar points out "the increasing prevalence of digital technology requires that teachers and students become more comfortable using this technology to facilitate instruction and learning. This digital transformation has the potential to change the ways that teachers instruct, how students learn and how course material is delivered" (Sivakumar, 2016).

The main aim of foreign language teaching at higher non-language educational institutions is to prepare specialists with practical knowledge of a foreign language accordingly to their future professional field. By this we mean acquiring skills of a foreign language proficiency in different spheres of speech activity on the subjects determined by all kinds of needs (personal, public, professional, educational) and improving the vocabulary and grammar skills, which are already acquired by completing various tasks and solving problems in order to build a high English-language professional communicative competence (National Strategy, 2013). That is the reason that the process of teaching English for specific purposes requires creating a blended learning environment, where students are able to not only access different 
materials and data but also participate in the construction of their own materials and projects actively. Thus we can speak definitely about new type of collaboration between teachers and students, in which teachers become rather facilitators than instructors or distributors of information. The main aim of such lessons is to solve various problems related to the future professional field in the friendly and collaborative atmosphere.

For example, third-year students of the "Agrarian engineering" speciality while studying the English language for specific (professional) purposes, at the stage of systematization of acquired knowledge, during the lesson on the topic: "Farm machines", are proposed to determine which model of the plough will provide the best soil preparation for cereals growing if the soil hardness is not more than $2.5 \mathrm{MPa}$, humidity is not more than $25 \%$ and the slope of the field surface is not more than $10^{\circ}$. The available tractors on the farm are of the traction class 3 with the engine capacity of $150 \ldots 170 \mathrm{hp}$.

To complete this task students are divided into several groups. Each member of the group has got a tablet PC with a pen or a stylus on the desk. All students' tablet PCs are connected via a local area network (LAN) or Wi-Fi network to each other and to the main computer. The teacher provides students with the access to the educational materials for the consolidation of the topic and preparing their own projects (LemeshchenkoLagoda, \& Kurashkin, 2019).

After working out the terms of the assignment, the students have to consider the main types of ploughs that can be used under the given conditions, analysing their advantages and disadvantages, agree on one best model and present their decision in the form of a minipresentation to the audience with further discussion. In this case, the tablet PC is used not only as a tool for searching and selecting information, but also for creating the project presentation itself. Students have the opportunity to repeat and / or review material provided by the teacher on the previous and current topic, use the online materials, make the necessary calculations, and create their own presentation material. Each member of the group tries to present the most appropriate plough model, making an attempt to prove reasonably his or her opinion to other team members, and after selecting one model, students are able to distribute certain tasks among themselves and prepare the whole project.

In their turn, students of the "Ecology" specialty can also check all the benefits of tablet PCs during their ESP course. Working out the topic "Energy conservation through wise consumption", students prepare their own projects on the possible ways of energy use. After reading the given newspaper article online and listening to the audio students have to find their own solutions taking into account not only the knowledge which has been accumulated during this particular lesson but also the previous experience. Thus, using tablet PCs students revise all of the material, look for important data and make their own presentations which are always displayed and discussed at the end of the lesson. These activities give students the opportunity to prepare for their future occupations and overcome different language and psychological barriers in order to build better relations with others and promote their ideas.

While studying the topic "Land use planning" fourth-year students of the "Land surveying" specialty also have the opportunity to complete their professional tasks with the help of tablet PCs. The possible task could be the following: A family has bought a new house. Banks want to know the exact acreage of land they are signing off for and insurance companies need to know how close their property lies to cricks, streams, or other hazards. Your task is to propose the ways of determining the exact boundaries of the property and preparing required documentation of boundary lines.

In order to do this task, students have to analyse different kinds of maps, archive documents and plans. All this is impossible without computers, and tablet PCs give an excellent opportunity to complete this task in short time. Then after analysing the areas students have to propose additional steps and measures that must be done to give fair measurements. Finally, they should make a list of required documents and provide the "owners" with all documentation that have to be done. 
After the completion of all of the given tasks the results should be stored so that the teacher could look them through, check and display them with the help of the projector, giving the students the opportunity to present their projects to others and in such a way to revise what they have learnt.

\section{CONCLUSIONS AND PERSPECTIVES FOR FURTHER STUDIES}

The conducted research makes it possible to point out all the benefits of using tablet PC technology in the classroom while teaching foreign languages. This technology gives the opportunity to prepare students for the future workplace, give them confidence and creative tools unrivalled by traditional classroom infrastructure, and engage those who are hard to reach and motivate.

In addition ESP teachers can provide students with information-rich content and encourage them to make their own presentations, diagrams, charts, schemes while teaching and revising grammar and vocabulary. At the same time, students become more engaged in the educational process, proposing their own examples, making suggestions and remarks, improving not only their written but also oral language skills.

In conclusion, it is necessary to point out that the introduction of tablet PC technologies into the practice of teaching the "English for specific purposes" course is a great opportunity to improve the communicative skills and build foreign language communicative competence of students of non-language specialities.

\section{REFERENCES}

Bovtruk, N. (2014). Tablet computer as a technical means of training students of technological education. In Proceedings of the VII International Scientific and Practical Conference "Information Education and Professional Communication
Technologies of the 21st Century" (pp. 306-313). (in Ukrainian)

Carrillo, A., Cejudo, J. M., Domínguez, F., \& Rodríguez, E. (2013). Graphics tablet technology in second year thermal engineering teaching. Journal of Technology and Science Education, 3(3), 102-112. DOI: http://dx.doi.org/10.3926/jotse.85. (in English)

Lemeshchenko-Lagoda, V., \& Kurashkin, O. (2019). Technology in the classroom: using graphics tablets for ESP lessons in agrarian and technical universities. Ukrainian Journal of Educational Studies and Information Technology, 7(2), 37-43. DOI: https://doi.org/10.32919/uesit.2019.02.05. (in English)

National Strategy for the Development of Education in Ukraine for the period up to 2021. (2013). Retrieved from http://zakon4.rada.gov.ua/laws/show/344/ 2013. (in Ukrainian)

Sandakov, D. (2013). Tablets in school and university: pros and cons. Retrieved from http://obrazovanie.by/sandakov/plansheti-vuchebe.html. (in Russian)

Semerci, A. (2018). Students' views on the use of tablet computers in education. World Journal on educational Technology, 10(2), 104-114. Retrieved from https://www.researchgate.net/publication/ 328510447_Students'_views_on_the _use_of_tablet_c omputers in_education. (in English)

Sivakumar, R. (2016). Tablet computers in education. Journal of Contemporary Educational research and Innovations, 6(6), 258-262. Retrieved from https://www.researchgate.net/publication/3263562 82_TABLET_COMPUTERS_IN_EDUCATION. (in English)

Tablets will change higher education. (2014). Retrieved from: http://ru.osvita.ua/vnz/high_school/42870/. (in Russian)

Yuzych, M., \& Shchedrov, D. (2013, August 1). Gadgets: And Entertainment, and Education. Day, 134. Retrieved from https://day.kyiv.ua/uk/article/ cuspilstvo/gadzheti-i-zabavka-i-osvita. (in Ukrainian)

\section{About the authors:}

Svitlana Symonenko, Candidate of Pedagogical Sciences, Head of the Department of Foreign Languages, Dmytro Motornyi Tavria State Agrotechnological University (18 B. Khmelnytsky Ave, Melitopol, Ukraine, 72310), ORCID: http://orcid.org/0000-0003-0599-3999, svitlana.symonenko@tsatu.edu.ua 
Viktoriia Lemeshchenko-Lagoda, Teacher of the Department of Foreign Languages, Dmytro Motornyi Tavria State Agrotechnological University (18 B. Khmelnytsky Ave, Melitopol, Ukraine, 72310), ORCID: https://orcid.org/0000-0002-1080-5510, viktoriia.lemeshchenko-lagoda@tsatu.edu.ua

Oleksandr Kurashkin, Student of the Mechanical and Technological Faculty, Dmytro Motornyi Tavria State Agrotechnological University (18 B. Khmelnytsky Ave, Melitopol, Ukraine, 72310), ORCID: https://orcid.org/00000002-8267-4695, o.kurashkin@gmail.com 